

日本語は，各品詞にわたって待遇表現が発達している。中でも動詞に関する待遇表現 は多岐にわたるが，待遇表現：「接頭辞オ十本動詞＋補助動詞 (オ〜型表現)」，および 「接頭辞ゴ十本動詞十補助動詞 (ゴ〜型表現)」は，日本語の動詞待遇表現における主要 な表現である，両表現の違いについては，才に続く本動詞が和語であり，ゴに続く本 動詞が漢語であるということが，従来の言語学的研究で指摘されてきた.しかし，両 表現の言語心理的な違いを定量的に調べた研究は，これまで殆どなかった.

今回，我々は，Scheffeの一対比較法を用いてオ〜型表現，およびゴ〜型表現に対して 人々が感じる丁寧さの程度を数值化した上で，統計的検定を行って丁寧さの印象に関 する両表現の違いを定量的に分析した。 その結果，ゴ〜型表現はオ〜型表現に比べ, 通常表現を待遇表現に変化させた場合に，通常表現からの丁寧さの変化量がより小さ いことが分かった。そして，その原因として，待遇表現としての認識に関する両表現 の違いが示唆された。

キーワード： 敬語形式，丁寧さ，Scheffeの一対比較法，定量化，統計的検定

\title{
Quantitative Analysis regarding Impressions of Politeness of Verbal-Honorific Expressions: Comparison of Expressions Using Prefixes "GO" and "O" Honorific Expressions
}

\author{
Satoko Marumoto ${ }^{\dagger}$, TAmotsu Shirado ${ }^{\dagger \dagger}$ and Hitoshi Isahara ${ }^{\dagger}$
}

\begin{abstract}
Expressions of "prefix O + main verb + auxiliary verb" and "prefix GO + main verb + auxiliary verb" are important verbal-honorific expressions in the Japanese language. It has been pointed out in past linguistic researches that the difference between the two types of expressions is that the main verb after " $\mathrm{O}$ " is a Japanese word and the one after "GO" is a Chinese word. However, there have hardly been any quantitative researches made on the differences of the two expressions so far.

In this study, quantitative analyses were performed to reveal differences in the impressions of politeness between these two types of expressions by using Scheffe's paired comparison method and statistical tests. Results suggest that in regard to difference in politeness from a plain form, "prefix GO + verb of Chinese word + auxiliary verb," is smaller than "prefix $\mathrm{O}+$ verb of Japanese word + auxiliary verb." It is suggested that these results are due to the difference between these expressions as to the recognition of honorific expressions.
\end{abstract}

KeyWords: honorific forms, politeness, Scheffe's paired comparison method, quantification, statistical tests

$\dagger$ (財) 計量計画研究所, The Institute of Behavioral Sciences

† (独) 情報通信研究機構, National Institute of Information and Communications Technology 


\section{1 はじめに}

待遇表現は日本語の特徵の一つである。敬語的な表現は他の言語にも見られるが，日本語の ように, 待遇表現を作るための特別な語彙や形式が体系的に発達している言語はまれである(水 谷 1995).

日本語の待遇表現は, 動詞, 形容詞, 形容動詞, 副詞, 名詞, 代名詞など, ほぼ全ての品詞 に見られる．特に，動詞に関する待遇表現は他の品詞に比べて多様性がある，具体的には，動 詞に関する待遇表現は，以下の 4 つのタイプに大別できる．1）「拉話しになる」や「ご説明す る」などのように，接頭辞オもしくは接頭辞ゴと動詞と補助動詞を組み合わせる，2）「おっしゃ る」と「申す」（いずれも通常表現 ${ }^{1}$ は「言う」）などのように動詞自体を交替させる，3）「話し て頂く」「話して下さる」「話してあげる」などのように助詞テを介して補助動詞が繋がる, 4)「ます」「れる」「られる」などの助詞・助動詞を動詞と組み合わせる，などがある．これら の中でも 1 つ目のタイプ(以下,「オ+本動詞＋補助動詞」を“オ〜型表現”,「ゴ十本動詞十補助 動詞」を “ゴ〜型表現”と呼ぶ) は, 同じ本動詞を用いた場合でも, 補助動詞との組み合わせに よって尊敬語になる場合と謙譲語になる場合がある, という複雑な特徵を持つ.

ここで, オ〜型表現とゴ〜型表現の違いについては, 形式に関しては, 原則的に, 接頭辞ゴ に続く本動詞が漢語動詞であり，接頭辞オに続く本動詞が和語動詞であるということが従来の 言語学的研究で指摘されてきた。しかし，その機能に関しては，接頭辞の違いは考慮せずに同 じ補助動詞を持つ表現をまとめて扱うことが多く，両者の違いについて言及されることは，こ れまで殆どなかった。

ところが, 待遇表現としての自然さの印象に関してオ〜型表現とゴ〜型表現を比較した先行 研究において，それが誤用である場合にも，才〜型表現に比べてゴ〜型表現は，概して，不自 然さの印象がより弱いという傾向が見られた. そしてその理由として, 待遇表現としての認識 に関するオ〜型表現とゴ〜型表現の違いが議論された (白土，丸元，井佐原 2003).

ここでもし，待遇表現としての認識に関して，オ〜型表現とゴ〜型表現の間で本質的な違い があるとするならば，自然さの印象だけでなく，待遇表現に関する他のさまざまな印象の違い としても観測できるはずである。そこで，本研究では，待遇表現の最も典型的な属性である丁 寧さに注目する。すなわち, 本研究は, 待遇表現の丁寧さの印象に関するオ〜型表現とゴ〜型 表現の違いについて定量的に調べることを目的とする.

1 いわゆる“敬語”は用いず，通常の言葉を用いた表現. 


\section{2 待遇表現の丁寧さの定量化}

\section{1 本研究における「待遇表現の丁寧さ」の捉え方}

待遇表現という言語現象は，(I) 話し手が，その具体的な人物や場面に関わる社会的・心理 的な諸要因を考慮した上で，問題の人物 (話題となる人物や聞き手など) に，あるレべルの待遇 を与えようとすることと (II) ある待遇表現を使うことで，その人物に，あるレベルの待遇を与 えることになる (という法則性がある)こと，に分けて考えることができる (菊池 2003). 社会 言語学的立場から待遇表現を体系的に整理している研究 (蒲谷, 川口, 坂本 1991) や, ポライト ネスに関する包括的な理論としてよく知られているブラウンとレビンソンの理論 (Brown and Levinson 1987) も同様に, (I) と (II) を分けて扱っている.ここで, (II)において, 問題の人物 に対してより高いレベルの待遇を与えるような待遇表現は，概して，人々がより丁寧な印象を 持つ表現であると考えられる。

本研究でも，(I) と (II) を分けて扱うことができるという考えに立ち，(II)で用いられる，い ろいろな待遇表現の丁寧さを，場面の設定は行わずに定量化する。

\section{2 丁寧さの定量化の方法}

荻野はクロス集計表に基づく待遇表現の定量化の研究において，ほとんど全ての待遇表現の 丁寧さは，一次元の值として表現できることを示した (荻野 1986). また，この仮定に基づいて Scheffe 法 (Scheffe 1952) を用いた実証例も報告されている (白土, 井佐原 2002).

本研究では, これらの結果をふまえ, いろいろな待遇表現に対して人々が感じる丁寧さの大 きさは，何らかの心理的な空間における一次元上の值として定量化できるものとする．丁寧さ の定量化の方法としては, 心理学的測定法として代表的な手法の一つである Scheffe の一対比較 法の中屋の変法 (中屋 1970; 三浦他 1973; 田中 1977) を用いる.

以下では, 定量化によって得られた, 表現の丁寧さを表す值を「待遇値」と呼ぶ. 本研究で はScheffe 法を用いているため, 待遇值は間隔尺度上の值, すなわち待遇表現間の丁寧さの相対 值を表す.

\section{3 オ〜型表現とゴ〜型表現の丁寧さに関する実験}

\section{1 本研究で注目する待遇表現のパタン}

本研究では, 表 1 に示すオ〜型表現, およびゴ〜型表現の主なパタンに注目する (林, 南 1974; 菊池 1997; 鈴木, 林 1984). ただし, ここでは, オ〜型表現, およびゴ〜型表現との比較 のために通常表現，および丁寧語 (ただし，「ます」を用いるパタンのみ) も含めることとした. 以下, 通常表現, 丁寧語，およびオ〜型表現を総称して「和語系表現」と呼び，通常表現，丁 
寧語，およびゴ〜型表現を総称して「漢語系表現」と呼ぶ.

表 1 の「」の部分は各パタンと組み合わされる本動詞，すなわち，オ〜型のパタンでは和 語動詞，ゴ〜型のパタンでは漢語動詞である ${ }^{2}$.また丁寧語「〜ます」のパタンでは和語動詞， 漢語動詞の両方である.

表 1 には，主な待遇表現のパタンとして二重敬語：「オ／ゴ〜になられる」も含めた。その 理由は，近年では二重敬語に抵抗を感じる人が少なく(文化庁文化部国語課 1995)，かつ待遇表 現としての自然さの印象に関する研究 (白土，丸元，井佐原 2003) においても，このパタンの表 現に対しては待遇表現としての自然さの印象が強かったためである.

表 1 本研究で注目する待遇表現のパタン

\begin{tabular}{|c|c|}
\hline 種類 & パタン \\
\hline 謙譲語 & $\begin{array}{l}\text { オ/ゴ〜する } \\
\text { オ/ゴ〜します } \\
\text { オ/ゴ〜できる } \\
\text { オ/ゴ〜できます } \\
\text { オ/ゴ〜致します } \\
\text { オ/ココ〜申します } \\
\text { オ/ゴ〜申し上げます } \\
\text { オ/ゴ〜頂く } \\
\text { オ/ゴ〜頂きます }\end{array}$ \\
\hline 尊敬語 & $\begin{array}{l}\text { オ/ゴ〜なさる } \\
\text { オ/ゴ〜なさいます } \\
\text { オ/ゴ〜になる } \\
\text { オ/ゴ〜になります } \\
\text { オ/ゴ〜下さる } \\
\text { オ/ゴ〜下さいます } \\
\text { オ/ゴ〜になられる (二重敬語) }\end{array}$ \\
\hline 丁寧語 & 〜ます \\
\hline 通常表現 &  \\
\hline
\end{tabular}

\section{2 実験刺激}

本実験では，複数個の発話意図に共通して見られる，オ〜型表現とゴ〜型表現の違いに関す る傾向を調べる。具体的な発話意図としては，その発話意図に対応した和語動詞と漢語動詞が 両方とも存在し，かつ表 1 のパタンと組み合わせることが可能なものを 5 種類，設定した (表 2).なお，表 2 左端には各発話意図にほほ対応する概念を表す英単語を示した.

実験に用いる表現グループは，謙譲語だけから成る表現グループと尊敬語だけから成る表現

2 具体的には, 5.3 節で述ベるように，オ〜型のパタンでは和語動詞の連用形，ゴ〜型のパタンでは漢語動詞の語幹，丁 寧語「〜ます」のパタンでは漢語動詞の語幹, 和語動詞の連用形である. 
表 2 発話意図とそれに対応する動詞

\begin{tabular}{cll}
\hline 発話意図 & 和語動詞 & 漢語動詞 \\
\hline answer & 答える & 回答する \\
use & 使う & 使用する \\
explain & 話す & 説明する \\
inform & 知らせる & 連絡する \\
invite & 招く & 招待する \\
\hline
\end{tabular}

グループに分けられる。この理由は，謙譲語と尊敬語では行為主体が異なるので（例えば，謙 讓語：「(私が $)$ 㧍答えする」，尊敬語：「(先生が $)$ 㧍答えになる」)，両者の対が被験者に呈示さ れた場合，比較が困難になるような状況が生じる可能性が否定できないためである。なお，通 常表現掞よび丁寧語は，謙譲語扔よび尊敬語と行為主体が同じであると解釈することが可能で あり，また，分析に用いる必要上，両方のグループに入れた。

表 2 に示した各発話意図における和語動詞，漢語動詞のそれぞれに対して，表 1 における謙 譲語 9 パタン+丁寧語 1 パタン+通常表現 1 パタン $=11$ パタン, および表 1 に抒ける尊敬語 7 パタン十丁寧語 1 パタン十通常表現 1 パタン = 9 パタンを組み合わせて, 2 つの表現グループ を作った(以下，それぞれの表現グループを謙譲語グループ，および尊敬語グループと呼ぶ).

発話意図：answerに対する表現グループの例を表 3.1(謙譲語), 表 3.2(尊敬語)に示す.

各行の左右の列には，同心゙補助動詞（「する」,「なさる」など）を持つ表現が対として記さ れている（ただし，通常表現扔よび丁寧語を除く）。表の左側の列には和語系表現，右側の列に は漢語系表現が記されている。


と No.12 が通常表現, No. 2 と No.13 が丁寧語, No.3〜No.11 と No.14〜No. 22 が謙譲語であり, 表 3.2 では, No.1 と No.10が通常表現, No.2 と No.11 が丁寧語, No.3〜No.9 と No.12〜No.18 が尊敬語である。

表 3.1, 表 3.2 と同様に, 発話意図：use，explain，inform および inviteに対して作った表現 グループを付表 1.1 付表 4.2 に示す. 以上のように, 本実験では, 発話意図 $: 5$ 種類 $\times$ 謙譲語 尊敬語： 2 種類=計 10 種類の表現グループを用いた。

\section{3 実験手続き}

実験では，上記の 10 種類の表現グループそれぞれにおいて，グループ内の全ての表現に対 する待遇值を求めた，定量化には，前述のようにScheffe の一対比較法の中屋の变法を用いた. 実験に扔ける回答形式および回答の例を図 1 に示す。

被験者は関東在住の 20 代 50 代の男女 80 人 (男女各 40 人) である. 被験者は一対ずつ呈 示された表現の間で丁寧さを比較し, 図中のケース 1 ケース 3 のそれぞれに応じて回答用紙 
表 3.1 発話意困 : answer, 謙譲語

\begin{tabular}{|c|l|c|l|}
\hline No. & \multicolumn{1}{|c|}{ 和語系表現 } & No. & \multicolumn{1}{|c|}{ 漢語系表現 } \\
\hline 1 & 答える & 12 & 回答する \\
\hline 2 & 答えます & 13 & 回答します \\
\hline 3 & お答えする & 14 & ご回答する \\
\hline 4 & お答えします & 15 & ご回答します \\
\hline 5 & お答えできる & 16 & ご回答できる \\
\hline 6 & お答えできます & 17 & ご回答できます \\
\hline 7 & お答え致します & 18 & ご回答致します \\
\hline 8 & お答え申します & 19 & ご回答申します \\
\hline 9 & お答え申し上げます & 20 & ご回答申し上げます \\
\hline 10 & お答え頂く & 21 & ご回答頂く \\
\hline 11 & お答え頂きます & 22 & ご回答頂きます \\
\hline
\end{tabular}

表 3.2 発話意図 : answer, 尊敬語

\begin{tabular}{|c|l|c|l|}
\hline No. & \multicolumn{1}{|c|}{ 和語系表現 } & No. & \multicolumn{1}{|c|}{ 漢語系表現 } \\
\hline 1 & 答える & 10 & 回答する \\
\hline 2 & 答えます & 11 & 回答します \\
\hline 3 & お答えなさる & 12 & ご回答なさる \\
\hline 4 & お答えなさいます & 13 & ご回答なさいます \\
\hline 5 & お答えになる & 14 & ご回答になる \\
\hline 6 & お答えになります & 15 & ご回答になります \\
\hline 7 & お答え下さる & 16 & ご回答下さる \\
\hline 8 & お答え下さいます & 17 & ご回答下さいます \\
\hline 9 & お答えになられる & 18 & ご回答になられる \\
\hline
\end{tabular}

の適切な位置に○を付けるよう指示された(ケース 1 ，ケース 2 と対称的なケースについても同 様).ただし，回答が困難なケース（すなわち，ケース4）についてはメを付けることを認め， このケースについては定量化の計算に加味しないこととした.

以上の実験で得られた，各表現グループにおける各表現の待遇値の，全被験者にわたる平均 值を $\mu$ と記す.ただし表現 $\mathrm{E}_{i}$ に対する $\mu$ を特定する場合は， $\mu_{i}$ と記す。ここで， $i$ は各表現グ ループの中での通し番号 (例えば，表 3.1 ，表 3.2 中の No.) である.

\section{4 実験結果}

表 3.1 および表 3.2 の表現に対して得られた $\mu$ を，それぞれ図 2.1 および図 2.2 に示す ${ }^{3}$. 図 中の数字は, 各表現 $\mathrm{E}_{i}$ の添数 $i$ の值を表す. 同様にして, 付表 1.1 付表 4.2 の各表現に対して 得られた $\mu$ を，それぞれ，付図 $1.1 〜$ 付図 4.2 に示す.

図において， $\mu_{i}$ が大きい表現 $\mathrm{E}_{i}$ 程，それに対して平均的な被験者が感じる丁寧さの程度が




ケース 1 : 左側の表現の方が右側の表現に比べ，非常に丁寧だと感じる場合

ご回答下さいます

答える



ケース 2 : 左側の表現の方が右側の表現に比べ，やや丁寧だと感じる場合

ご回答になります、お答えになる

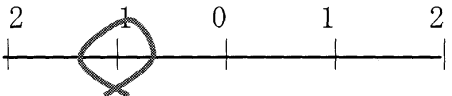

ケース 3：両表現が同じ程度に丁寧(もしくは，ぞんざい)だと感じる場合

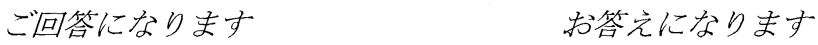



ケース 4：待遇表現としての丁寧さの比較が困難な場合

お答えになられる お答えになります

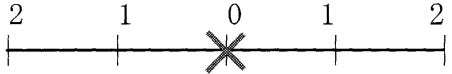

図 1 回答形式および回答の例

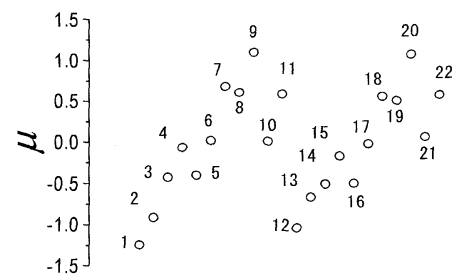

図 $2.1 \mu$ (発話意図：answer, 謙譲語)

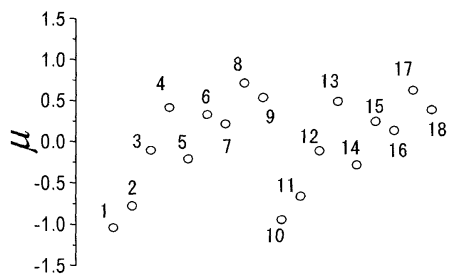

図 $2.2 \mu$ (発話意図：answer，尊敬語)

大きいことを表す。

本研究で用いた二重敬語（すなわち,「オ／ゴ〜になられる」）の丁寧さについては，他の表 現（すなわち，規範的な表現）と同様の傾向が見られた。例えば，図 2.2 , 付図 $1.2,2.2,3.2$, 4.2 の全てにおいて,「オ/ゴ〜になられる」(二重敬語) の待遇值は,「オ／ゴ〜になる」(「オ／ 
ゴ〜になられる」と最も形が似ており，かつモーラ数がより短い規範的な待遇表現)の待遇値よ り大きかった。これは，規範的な待遇表現に関する特徵：“モーラ数がより長い待遇表現は概し て，より丁寧に感じられる”(荻野 1980) と一致する.

また, 被験者がメを付けた表現ペア, すなわち, 被験者が待遇表現としての丁寧さの比較 が困難と判断したものは，4,279 ペアであった。これは，回答全体の $2.7 \%$ に相当する．このう ち $75 \%$ は，特定の 10 人に偏っていた。ただし，この 10 人に関して，年齢や性別に関する偏り は見られなかった。さらに，比較が困難とされた表現ぺアには特定の表現への偏りは見られな かった。

\section{5 考察}

\section{1 和語系表現と漢語系表現の比較}

前述の通り, 表 3.1, 表 3.2, 付表 1.1 付表 4.2 の各行には, 接頭辞十本動詞, が異なり（左 側の列はオ十和語動詞，右側の列はゴ＋漢語動詞），補助動詞（「する」,「なさる」など）が同 じである表現が対となって記されている。

ここでは，このように対となる表現の間で $\mu$ の差 ( $d$ と記す) を式 (1) で計算することによっ て, 同じ補助動詞を持つ和語系表現と漢語系表現の間での, 平均的な被験者の待遇值の違いを 調べる.

$$
d=\mu_{i+n}-\mu_{i} \quad(i=1, \ldots, n)
$$

式 (1) 右辺第一項は漢語系表現の $\mu$ ，第二項は和語系表現の $\mu$ である.ここで， $i$ は表現 $\mathrm{E}_{i}$ の添数 $i$ を表し, $n$ は謙譲語に対しては 11 , 尊敬語に対しては 9 である.すなわち, 式 (1)で は，表 4 に示す計算を行っている.

図 2.1 , および図 2.2 に示した $\mu$ に対し, 以上の方法で得た $d$ を図 3.1 , および図 3.2 に示す. 図中の記号 $(\mathrm{A}, \mathrm{B}, \cdots, \mathrm{K})$ は，表 4 のラベルに対応する.

図 3.1 および図 3.2 のいずれも， $\mathrm{A}$ (通常表現) および $\mathrm{B}$ (丁寧語) の $d$ が正, すなわち漢語系 表現の $\mu$ が和語系表現の $\mu$ より大きいことを示す。他の全ての表現グループにおいても，これ と同様の傾向が見られた (付図 5.1〜付図 8.2). [結果 (1)]

一方, $\mathrm{A}$ (通常表現) および $\mathrm{B}$ (丁寧語) 以外の語 (すなわち, 尊敬語や謙譲語) の $d$ は, 值の正 負に関する一貫した傾向はなかった，他の全ての表現グループにおいても，これと同様であっ た (付図 5.1〜付図 8.2). 
表 4 d の計算方法

\begin{tabular}{ccc}
\hline ラベル & 謙譲語グループ & 尊敬語グループ \\
\hline $\mathrm{A}$ & $\mu_{12}-\mu_{1}$ & $\mu_{10}-\mu_{1}$ \\
$\mathrm{~B}$ & $\mu_{13}-\mu_{2}$ & $\mu_{11}-\mu_{2}$ \\
$\mathrm{C}$ & $\mu_{14}-\mu_{3}$ & $\mu_{12}-\mu_{3}$ \\
$\mathrm{D}$ & $\mu_{15}-\mu_{4}$ & $\mu_{13}-\mu_{4}$ \\
$\mathrm{E}$ & $\mu_{16}-\mu_{5}$ & $\mu_{14}-\mu_{5}$ \\
$\mathrm{~F}$ & $\mu_{17}-\mu_{6}$ & $\mu_{15}-\mu_{6}$ \\
$\mathrm{G}$ & $\mu_{18}-\mu_{7}$ & $\mu_{16}-\mu_{7}$ \\
$\mathrm{H}$ & $\mu_{19}-\mu_{8}$ & $\mu_{17}-\mu_{8}$ \\
$\mathrm{I}$ & $\mu_{20}-\mu_{9}$ & $\mu_{18}-\mu_{9}$ \\
$\mathrm{~J}$ & $\mu_{21}-\mu_{10}$ & - \\
$\mathrm{K}$ & $\mu_{22}-\mu_{11}$ & - \\
\hline
\end{tabular}

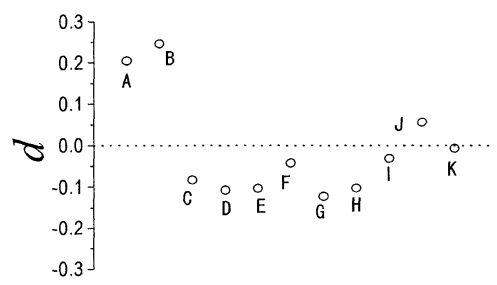

図 $3.1 d$ (発話意図：answer, 謙譲語)

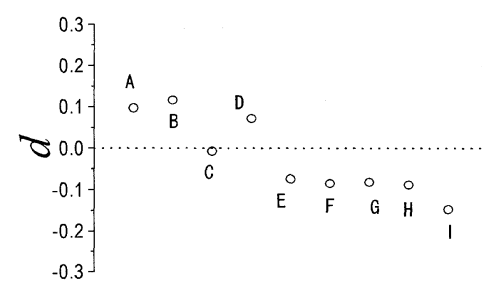

図 $3.2 d$ (発話意図：answer，尊敬語)

\section{2 通常表現からの变化に関する，才〜型表現とゴ〜型表現の比較}

前節で述べたように，同じ補助動詞を持つオ〜型表現（「オ十和語動詞十補助動詞」）とゴ 〜型表現（「ゴ+漢語動詞＋補助動詞」）の間では，通常表現および丁寧語を除き，両者の $\mu$ の 差, すなわち $d$ に関する一貫した傾向は見られなかった. しかし， $d$ はオ十〜十補助動詞」と 「ゴ+〜+補助動詞」の違いのみならず,「〜」の部分, すなわち, 和語動詞と漢語動詞の違いを 反映した指標であるため, ここでは, 和語動詞と漢語動詞の違いの影響をできるだけ排除して, オ〜型表現とゴ〜型表現の間で丁寧さの印象に関する特性の違いをさらに調べることとする. このためには，表現全体としての $\mu$ ではなく和語動詞単体 (通常表現) から「オ十和語動詞十補 助動詞」に変化させたことによる $\mu$ の変化量, および漢語動詞単体 (通常表現) から「ゴ十漢語 動詞＋補助動詞」に変化させたことによる $\mu$ の変化量の間で比較を行えば良い.すなわち, 各 表現（通常表現を除く）の $\mu$ をその通常表現の $\mu$ からの変化量として補正した值（これを $\mu^{\prime} と$ 記す）に関して，オ〜型表現とゴ〜型表現の差（ $\delta$ と記す）を次式で計算する.

$$
\delta=\mu_{i+n}^{\prime}-\mu_{i}^{\prime} \quad(i=2, \ldots, n)
$$


ただし,$\mu_{i+n}^{\prime}=\mu_{i+n}-\mu_{n+1}$ (漢語動詞. $\mu_{n+1}$ は通常表現の $\left.\mu\right), \mu_{i}^{\prime}=\mu_{i}-\mu_{1}$ (和語動詞. $\mu_{1}$ は通常表現の $\left.\mu\right), n$ は式 $(1)$ と同様, 謙譲語に対しては 11 , 尊敬語に対しては 9 である.す なわち, 式 (2) では, 表 5 に示す計算を行っている.

なお, ラベル B の $\delta$ は丁寧語であるため接頭辞オノゴは含まないが，オ〜型表現，およびゴ 〜型表現との比較のため示した.

表 $5 \quad \delta$ の計算方法

\begin{tabular}{ccc}
\hline ラベル & 謙譫語グループ & 尊敬語グループ \\
\hline $\mathrm{B}$ & $\left(\mu_{13}-\mu_{12}\right)-\left(\mu_{2}-\mu_{1}\right)$ & $\left(\mu_{11}-\mu_{10}\right)-\left(\mu_{2}-\mu_{1}\right)$ \\
$\mathrm{C}$ & $\left(\mu_{14}-\mu_{12}\right)-\left(\mu_{3}-\mu_{1}\right)$ & $\left(\mu_{12}-\mu_{10}\right)-\left(\mu_{3}-\mu_{1}\right)$ \\
$\mathrm{D}$ & $\left(\mu_{15}-\mu_{12}\right)-\left(\mu_{4}-\mu_{1}\right)$ & $\left(\mu_{13}-\mu_{10}\right)-\left(\mu_{4}-\mu_{1}\right)$ \\
$\mathrm{E}$ & $\left(\mu_{16}-\mu_{12}\right)-\left(\mu_{5}-\mu_{1}\right)$ & $\left(\mu_{14}-\mu_{10}\right)-\left(\mu_{5}-\mu_{1}\right)$ \\
$\mathrm{F}$ & $\left(\mu_{17}-\mu_{12}\right)-\left(\mu_{6}-\mu_{1}\right)$ & $\left(\mu_{15}-\mu_{10}\right)-\left(\mu_{6}-\mu_{1}\right)$ \\
$\mathrm{G}$ & $\left(\mu_{18}-\mu_{12}\right)-\left(\mu_{7}-\mu_{1}\right)$ & $\left(\mu_{16}-\mu_{10}\right)-\left(\mu_{7}-\mu_{1}\right)$ \\
$\mathrm{H}$ & $\left(\mu_{19}-\mu_{12}\right)-\left(\mu_{8}-\mu_{1}\right)$ & $\left(\mu_{17}-\mu_{10}\right)-\left(\mu_{8}-\mu_{1}\right)$ \\
$\mathrm{I}$ & $\left(\mu_{20}-\mu_{12}\right)-\left(\mu_{9}-\mu_{1}\right)$ & $\left(\mu_{18}-\mu_{10}\right)-\left(\mu_{9}-\mu_{1}\right)$ \\
$\mathrm{J}$ & $\left(\mu_{21}-\mu_{12}\right)-\left(\mu_{10}-\mu_{1}\right)$ & - \\
$\mathrm{K}$ & $\left(\mu_{22}-\mu_{12}\right)-\left(\mu_{11}-\mu_{1}\right)$ & - \\
\hline
\end{tabular}

図 2.1 および図 2.2 に示した $\mu$ に対し, 以上の方法で得た $\delta$ を図 4.1 および図 4.2 に示す.

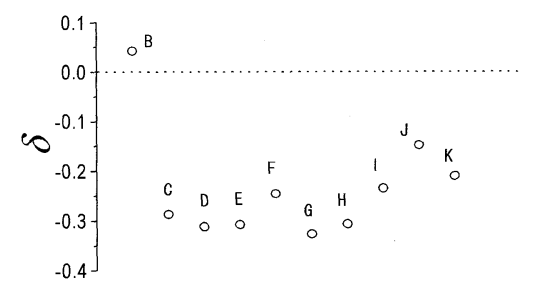

図 $4.1 \delta$ (発話意図：answer, 謙譲語)

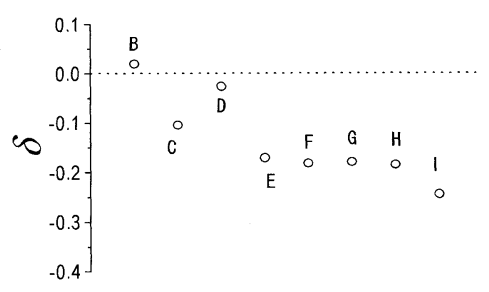

図 $4.2 \delta$ (発話意図：answer，尊敬語)

図 4.1 および図 4.2 を見ると, $\mathrm{B}$ (丁寧語) に対する $\delta$ を除き, 全ての $\delta$ の值は負であること が分かる. 他の全ての表現グループにおいても，1つの例外 (付図 11.2 の C) を除き, 全ての $\delta$ は負であった (付図 9.1〜付図 12.2).

そこで, 各表現グループにおいて, 帰無仮説: $\bar{\delta}=0$ の検定 (石村 1989) を行った(表 6). こ こで, $\bar{\delta}$ は, 各表現グループにおいて, $\mathrm{B}$ (丁寧語)を除く全ての表現にわたる $\delta$ 平均を表す. 表 6 は, 10 種類の表現グループいずれにおいても兴無仮説 : $\bar{\delta}=0$ が育却されることを示す 
（有意水準 $1 \% ）$ ．かつ， $\bar{\delta}$ は負である．従って， $\bar{\delta}$ は有意に 0 より小さい。これは，通常表現か らの変化量 $\mu^{\prime}$ に関し，ゴ〜型表現の平均的な $\mu^{\prime}$ は，それに対応する(すなわち，同じ補助動詞 を持つ) オ〜型表現の平均的な $\mu^{\prime}$ より有意に小さいことを示唆する. [結果 (2)]

表 $6 \bar{\delta}=0$ の検定結果

\begin{tabular}{|c|c|c|c|c|}
\hline 発話意図 & 謙譲語/尊敬語 & $\bar{\delta}$ & 検定量 $T$ & 自由度 \\
\hline \multirow{2}{*}{ answer } & 謙譲語 & -0.264 & 13.4 & 8 \\
\hline & 尊敬語 & -0.156 & 5.8 & 6 \\
\hline \multirow{2}{*}{ use } & 謙譲語 & -0.194 & 7.1 & 8 \\
\hline & 尊敬語 & -0.220 & 12.7 & 6 \\
\hline \multirow{2}{*}{ explain } & 謙譲語 & -0.110 & 5.9 & 8 \\
\hline & 尊敬語 & -0.171 & 11.5 & 6 \\
\hline \multirow{2}{*}{ inform } & 謙譲語 & -0.103 & 8.4 & 8 \\
\hline & 尊敬語 & -0.114 & 4.2 & 6 \\
\hline \multirow{2}{*}{ invite } & 謙譲語 & -0.271 & 13.3 & 8 \\
\hline & 尊敬語 & -0.301 & 14.8 & 6 \\
\hline
\end{tabular}

また，図 4.1 および図 4.2 のいずれも，B(丁寧語) の $\delta$ が正であることを示す．図 4.1, 図 4.2 , 付図 9.1 付図 12.2 と合わせ，全部で 10 個の表現グループのうち，5個 $(50 \%)$ において $\mathrm{B}$ (丁寧語) の $\delta$ が正であった。[結果 (3)]

\section{3 オ〜型表現とゴ〜型表現に差異が生じた理由}

前節の結果 $(2)$ に示したように，ゴ〜型表現の平均的な $\mu^{\prime}$ (通常表現の $\mu$ からの变化量) は,

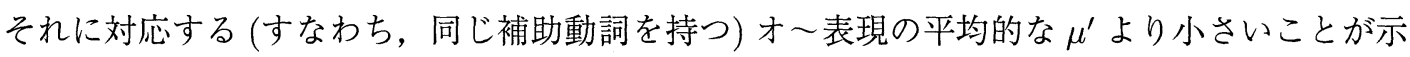
唆された. 以下では, この理由について考察する.

\section{解釈 1）一体感の違いに基づく解釈}

オ〜型表現とゴ〜型表現の丁寧さの印象の差異は，それぞれの本動詞の活用形（和語動詞の 場合は和語動詞連用形，漢語動詞の場合は漢語動詞語幹）が動詞転成名詞の語形と一致してい ることに起因すると考えられる。ここで, 動詞転成名詞とは, 和語動詞の場合は和語動詞連用 形が名詞の性質を持ったものである．漢語動詞の場合は漢語動詞 (サ変動詞) 語幹が名詞の性質 を持ったものであり，いわゆるサ変名詞に相当する.

具体的には，ゴ〜型表現は「ゴ回答」「ゴ招待」のように「ゴ+漢語動詞語幹」のみで独立 した表現（すなわち，サ変名詞としての用法）として用いられることが多い.このため,「ゴ+ 漢語動詞語幹」が現れた時に，その表現だけで動詞転成名詞としての待遇表現が成立している と認識し, 後続する表現, すなわち補助動詞への意識が低くなっている可能性がある. 
一方，オ〜型表現の場合,「オ十和語動詞連用形」は動詞転成名詞であり形としては正しい が,「オ使い」「オ招き」のように,「オ十和語動詞連用形」の部分だけでは, 動詞転成名詞として は，ゴ〜型表現に比べて，あまり用いられないことが考えられる。このため,「オ十和語動詞連 用形」が現れた時に，その表現だけで待遇表現が成立しているとは認識せずに，後続する表現， すなわち補助動詞に意識が及びやすくなっている可能性がある.つまり，オ〜型表現では，接 頭辞と本動詞だけでなく, 補助動詞まで確認した上で表現としての適切さや丁寧さの程度を判 断しようとしていると言える.

このことは，接頭辞オと接頭辞ゴの間には，本動詞との一体感の印象に差異がある，すなわ ち, ゴと漢語動詞の一体感は，オと和語動詞の一体感より強いことを示唆する.ゴ〜型表現の 方が接頭辞と本動詞の一体感がより強いため, 通常表現に接頭辞が付いて待遇表現になったこ とへの印象がオ〜型表現に比べて弱かったと考えられる，そしてその結果，通常表現からの待 遇值の変化量がより小さくなったと考えられる.

しかし，この解釈の他に次の解釈も可能である.

\section{解釈 2) ある種の飽和現象の仮定に基づく解釈}

前述のように結果 $(2)$ は, 通常表現からの待遇値の変化量 $\mu^{\prime}$ に関するオ〜型表現とゴ〜型 表現の比較による。このため, ある種の飽和現象: “通常表現の待遇值 $\mu$ が大きい程, 通常表現 に接頭辞や語尾 (丁寧語の場合は語尾のみ) を付加してモーラ数を長くした時の $\mu$ の変化量は小 さくなる (変化量が鈍化する)”，が存在すると仮定するならば，今回の実験では，全ての表現グ ループにおいて漢語動詞は和語動詞に比べ通常表現の $\mu$ の值が大きかった（結果 $(1)$ ）ため, 通

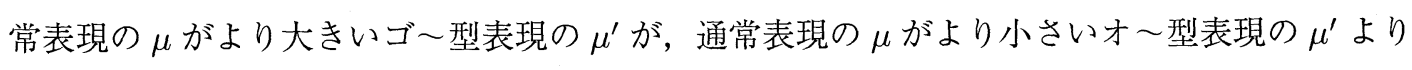
小さくなった，という説明が可能である.

しかし，この解釈は結果 (3)（10 個の表現グループのうち，5 個 $(50 \%)$ において B(丁寧語) の $\delta$ が正であった) とは必ずしも一致しない.すなわち, 結果 $(3)$ のうち, 丁寧語 (接頭辞を用

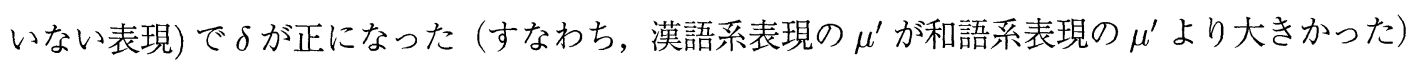
表現グループ（全体の $50 \%$ ）に対しては，この解釈では説明できない.

以上のことから, 解釈 1 は本実験結果に対するより妥当な解釈であると考えられる.すなわ ち動詞待遇表現に関しては, 後続する本動詞との一体感に関する接頭辞ゴと接頭辞オの違いが, 通常表現からの待遇値の変化量に関するオ〜型表現とゴ〜型表現の違いとして現れたと解釈で きる。 


\section{4 同じグループに属する表現間の丁寧さの印象のばらつきに関する， オ〜型表現とゴ〜型表現の比較}

前節に述べた解釈 1 からは，ゴ〜型表現グループはオ〜型表現グループに比べて，同じ表現 グループに属する表現間を区別して認識する度合いがより小さいことが予測される。この時， ゴ〜型表現グループの方がオ〜型表現グループより, 同じ表現グループに属する表現間の待遇 值 $\mu$ の違いが小さくなることが予測される，この予測を確かめるため，ここでは，ゴ〜型表現

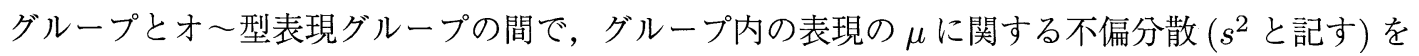
比較する. この時, $s^{2}$ が大きい程, そのグループにおける表現間での $\mu$ の違いが大きいことを 意味する．従って，オ〜型表現にわたる $s^{2}$ とゴ〜型表現にわたる $s^{2}$ とを比較することによっ て, それぞれの表現型に属する表現の間での丁寧さの印象の違いを，オ〜型表現とゴ〜型表現 との間で比較することができる。

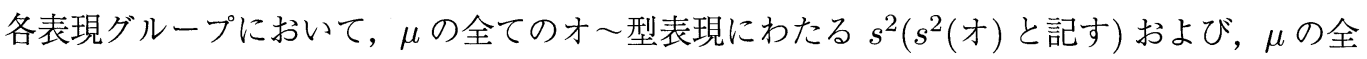
てのゴ〜型表現にわたる $s^{2}\left(s^{2}(コ ゙)\right.$ と記す) をそれぞれ求めた結果を表 7 に示す.

表 7 オ〜型表現とゴ〜型表現の比較

\begin{tabular}{|c|c|c|c|}
\hline 発話意図 & 謙譲語/尊敬語 & オ〜型/ゴ〜型 & $s^{2}$ (不偏分散) \\
\hline \multirow{4}{*}{ answer } & \multirow{2}{*}{ 謙譲語 } & 才〜型 & 0.279 \\
\hline & & ゴ〜型 & 0.289 \\
\hline & \multirow{2}{*}{ 尊敬語 } & 才〜型 & 0.110 \\
\hline & & ゴ〜型 & 0.106 \\
\hline \multirow{4}{*}{ use } & \multirow{2}{*}{ 謙譲語 } & オ〜型 & 0.225 \\
\hline & & ゴ〜型 & 0.221 \\
\hline & \multirow{2}{*}{ 尊敬語 } & 才〜型 & 0.078 \\
\hline & & ゴ〜型 & 0.082 \\
\hline \multirow{4}{*}{ explain } & \multirow{2}{*}{ 謙譲語 } & 才〜型 & 0.353 \\
\hline & & ゴ〜型 & 0.303 \\
\hline & \multirow{2}{*}{ 尊敬語 } & 才〜型 & 0.130 \\
\hline & & ゴ〜型 & 0.109 \\
\hline \multirow{4}{*}{ inform } & \multirow{2}{*}{ 謙譫語 } & 才〜型 & 0.328 \\
\hline & & ゴ〜型 & 0.334 \\
\hline & \multirow{2}{*}{ 尊敬語 } & 才〜型 & 0.118 \\
\hline & & ゴ〜型 & 0.116 \\
\hline \multirow{4}{*}{ invite } & \multirow{2}{*}{ 謙譲語 } & 才〜型 & 0.342 \\
\hline & & ゴ〜型 & 0.332 \\
\hline & \multirow{2}{*}{ 尊敬語 } & 才〜型 & 0.118 \\
\hline & & ゴ〜型 & 0.103 \\
\hline
\end{tabular}

表 7 から, 10 個の表現グループのうち 7 個の表現グループで, $s^{2}($ オ $)>s^{2}($ ゴ) であること が分かる.

この結果は, 概して, オ〜型表現に比べてゴ〜型表現は, 同じグループに属する表現間の待 
遇值 $\mu$ の違いの差が小さいことを示唆する。これは先の予測と一致する. 従って，この結果は 解釈 1 の妥当性を支持する.

このことから，同じ表現グループに属する表現間での丁寧さの印象 (待遇値)に関する比較 によっても，オ〜型表現とゴ〜型表現の間には，接頭辞と後続の語との一体感の違いに起因す る心理的印象の違いが生じていることが示唆された。

\section{6 おわりに}

待遇表現に対する丁寧さの印象に関し，オ〜型表現（「オ十和語+補助動詞」）とゴ〜型表現 （「ゴ十漢語＋補助動詞」）の違いを定量的に調べた。その結果，丁寧さの大きさに関し，オ〜型 表現に比べてゴ〜型表現は，

- 通常表現からの変化量がより小さいこと

・ その表現グループに属する表現間の違いがより小さいこと

が示唆された，その原因として，待遇表現としての認識に関する両者の違いが示唆された.す なわち，従来，同じ補助動詞の場合には，まとめて扱われることの多かったオ〜型表現とゴ〜 型表現の間には，接頭辞と後続の語との一体感の違いに起因する心理的印象の違いが生じてい ることが示唆された。

待遇表現の自然さの印象 (白土, 丸元, 井佐原 2003) だけでなく, 待遇表現の丁寧さの印象 に関しても，オ〜型表現とゴ〜型表現の間に差異が見られたことから，両者の間には，本質的 な違いがあると考えられる。これが適切だとすると，待遇表現に関する教育においても，両者 に違いがあるということを考慮する必要があるのではないか. すなわち，ゴ〜型表現はオ〜型 表現に比べ，表現間の区別のしにくさに起因した誤用が多いことから，オ〜型表現とゴ〜型表 現を学習させる場合には，両者を接頭辞だけが異なり，他は等価なものとして教えるのではな く，ゴ〜型表現の方が区別がしにくく間違いやすい，ということを教えた方が良い可能性があ る.このように本研究での知見は，教育上の一つの指針になりうる.

本研究で対象としたようなオノゴ〜型表現は, “〜”の部分に様々な動詞を当てはめること ができ, かつ動詞に続く様々な補助動詞と組み合わせることができるため, 非常に多くのバリ エーションが存在する。今回はオノゴ〜型表現のうち, 一部の表現のみを対象としたが, 本稿 で述べた手法を用いて，より多くのオ/ゴ〜型表現，“〜”の部分（動詞）の終止形，および “〜”の動詞を交替した表現（例：「言う」に対する「おっしゃる」）の丁寧さの程度の数值化を 行うことにより，多くの表現に関してその表現と丁寧さの程度との対応データが作成できる. このデー夕は, 例えば文生成の研究において, 様々な丁寧さを持つ様々な待遇表現を柔軟に生 成する際に役に立つと考えられる。この際，本研究で得られた知見に基づくと，例えば，同じ 程度の丁寧さを持った表現を数多く生成するためにはゴ〜型表現を優先的に用い，一方，丁寧 さの違いが大きい表現を数多く生成するためには，才〜型表現を優先的に用いる，などのよう 
に対処すれば良いと考えられる。

待遇表現としての認識は, 被験者の年齢や性別などにも依存する可能性がある，従って今後 は，これらの被験者属性への依存性について検討する予定である.

\section{参考文献}

Brown, P. and Levinson, S. (1987). Politeness - Some universals of language usage -. Cambridge.

文化庁文化部国語課 (1995). 国語に関する世論調査 平成 7 年 4 月調査. 大蔵省印刷局.

林四郎, 南不二男（編）（1974）. 敬語講座 1 敬語の体系. 明治書院.

石村貞夫 (1989). 統計解析のはなし. 東京困書.

蒲谷宏, 川口義一, 坂本恵 (1991). “待遇表現研究の構想.” 早稲田大学日本語研究教育センター 紀要 3, pp. 1-22.

菊池康人 (1997). 敬語. 講談社.

菊池康人 (2003). “敬語とその主な研究テーマの概観.”朝倉日本語講座 8 敬語. 朝倉書店.

三浦新 他（編）（1973）. 官能検査ハンドブック. 日科技連.

水谷静夫 (1995). 待遇表現提要. 計量計画研究所.

中屋澄子 (1970). “Scheffe の一対比較法の一変法.”第 11 回官能検査大会報文集. 日本科学技術 連盟.

荻野綱男 (1980). “敬語表現の長さと丁寧さ 札幌における敬語調査から (3).”計量国語学, 12

(6), pp. 264-271.

荻野綱男 (1986). “待遇表現の社会言語学的研究.” 日本語学, 5 (12), pp. 55-63.

Scheffe, H. (1952). "An analysis of variance for paired comparisons." J. Am. Statist. Assoc., 47, pp. 381-400.

白土保, 井佐原均 (2002). “待遇表現選択ストラテジの数值モデル.”電子情報通信学会論文誌, J85-A (3), pp. 389-397.

白土保, 丸元聡子, 井佐原均 (2003). “敬語に対する認識の混乱に関する定量的分析.” 計量国 語学, 24 (2), pp. 65-80.

鈴木一彦, 林巨樹 (編) (1984). 研究資料日本文法 9 敬語法編. 明治書院.

田中良久 (1977). 心理学的測定 第 2 版. 東京大学出版会. 


\section{付録}

付表 1.1 発話意図：use, 謙譲語

\begin{tabular}{|c|l|c|l|}
\hline No. & \multicolumn{1}{|c|}{ 和語系表現 } & No. & \multicolumn{1}{|c|}{ 漢語系表現 } \\
\hline 1 & 使う & 12 & 使用する \\
\hline 2 & 使います & 13 & 使用します \\
\hline 3 & お使いする & 14 & ご使用する \\
\hline 4 & お使いします & 15 & こ使用します \\
\hline 5 & お使いできる & 16 & ご使用できる \\
\hline 6 & お使いできます & 17 & ご使用できます \\
\hline 7 & お使い致します & 18 & ご使用致します \\
\hline 8 & お使い申します & 19 & ご使用申します \\
\hline 9 & お使い申し上げます & 20 & こ使用申し上げます \\
\hline 10 & お使い頂く & 21 & ご使用頂く \\
\hline 11 & お使い頂きます & 22 & ご使用頂きます \\
\hline
\end{tabular}

付表 2.1 発話意図：explain, 謙讓語

\begin{tabular}{|c|l|c|l|}
\hline No. & \multicolumn{1}{|c|}{ 和語系表現 } & No. & \multicolumn{1}{|c|}{ 漢語系表現 } \\
\hline 1 & 話す & 12 & 説明する \\
\hline 2 & 話します & 13 & 説明します \\
\hline 3 & お話しする & 14 & ご説明する \\
\hline 4 & お話しします & 15 & ご説明します \\
\hline 5 & お話しできる & 16 & ご説明できる \\
\hline 6 & お話しできます & 17 & ご説明できます \\
\hline 7 & お話し致します & 18 & ご説明致します \\
\hline 8 & お話し申します & 19 & ご説明申します \\
\hline 9 & お話し申し上けまます & 20 & ご説明申し上げます \\
\hline 10 & お話し頂く & 21 & ご説明頂く \\
\hline 11 & お話し頂きます & 22 & ご説明頂きます \\
\hline
\end{tabular}

付表 3.1 発話意図: inform, 謙譲語

\begin{tabular}{|c|l|c|l|}
\hline No. & \multicolumn{1}{|c|}{ 和語系表現 } & No. & \multicolumn{1}{|c|}{ 漢語系表現 } \\
\hline 1 & 知らせる & 12 & 連絡する \\
\hline 2 & 知らせます & 13 & 連絡します \\
\hline 3 & お知らせする & 14 & ご連絡する \\
\hline 4 & お知らせします & 15 & ご連絡します \\
\hline 5 & お知らせできる & 16 & ご連絡できる \\
\hline 6 & お知らせできます & 17 & ご連絡できます \\
\hline 7 & お知らせ致します & 18 & ご連絡致します \\
\hline 8 & お知らせ申します & 19 & ご連絡申します \\
\hline 9 & お知らせ申し上けまます & 20 & ご連絡申し上げます \\
\hline 10 & お知らせ頂く & 21 & ご連絡頂く \\
\hline 11 & お知らせ頂きます & 22 & ご連絡頂きます \\
\hline
\end{tabular}

付表 4.1 発話意図 : invite, 謙譲語

\begin{tabular}{|c|l|c|l|}
\hline No. & \multicolumn{1}{|c|}{ 和語系表現 } & No. & \multicolumn{1}{|c|}{ 漢語系表現 } \\
\hline 1 & 招く & 12 & 招待する \\
\hline 2 & 招きます & 13 & 招待します \\
\hline 3 & お招きする & 14 & ご招待する \\
\hline 4 & お招きします & 15 & ご招待します \\
\hline 5 & お招きできる & 16 & ご招待できる \\
\hline 6 & お招きできます & 17 & ご招待できます \\
\hline 7 & お招き致します & 18 & ご招待致します \\
\hline 8 & お招き申します & 19 & ご招待申します \\
\hline 9 & お招き申し上げます & 20 & ご招待申し上げます \\
\hline 10 & お招き頂く & 21 & ご招待頂く \\
\hline 11 & お招き頂きます & 22 & ご招待頂きます \\
\hline
\end{tabular}

付表 1.2 発話意図：use，尊敬語

\begin{tabular}{|c|c|c|c|}
\hline No. & 和語系表現 & No. & 漢語系表現 \\
\hline 1 & 便う & 10 & 便用する \\
\hline 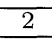 & 使います & 11 & 便用します \\
\hline 3 & お使いなさる & 12 & ご使用なさる \\
\hline 4 & お使いなさいます & 13 & ご使用なさいます \\
\hline 5 & お使いになる & 14 & ご使用になる \\
\hline 6 & お使いになります & 15 & ご使用になります \\
\hline 7 & 扔使い下さる & 16 & ご使用下さる \\
\hline 8 & お使い下さいます & 17 & ご使用下さいます \\
\hline$\overline{9}$ & 招便いになられる & 18 & ご使用になられる \\
\hline
\end{tabular}

付表 2.2 発話意図 : explain, 尊敬語

\begin{tabular}{|c|c|c|c|}
\hline No. & 和語系表現 & No. & 漢語系表現 \\
\hline 1 & 話す & 10 & 説明する \\
\hline 2 & 話します & 11 & 説明します \\
\hline 3 & 押話しなさる & 12 & ご説明なさる \\
\hline 4 & お話しなさいます & 13 & ご説明なさいます \\
\hline 5 & お話しになる & 14 & ご説明になる \\
\hline 6 & 抒話しになります & 15 & ご説明になります \\
\hline 7 & お話し下さる & 16 & ご説明下さる \\
\hline 8 & お話し下さいます & 17 & ご説明下さいます \\
\hline 9 & お話しになられる & 18 & ご説明になられる \\
\hline
\end{tabular}

付表 3.2 発話意図：inform, 尊敬語

\begin{tabular}{|c|c|c|c|}
\hline No. & 和語系表現 & No. & 漢語系表現 \\
\hline 1 & 知らせる & 10 & 連絡する \\
\hline 2 & 知らせます & 11 & 連絡します \\
\hline 3 & お知らせなさる & 12 & ご連絡なさる \\
\hline 4 & お知らせなといます & 13 & ご連絡なさいます \\
\hline 5 & お知らせになる & 14 & ご連絡になる \\
\hline 6 & お知らせになります & 15 & ご連絡になります \\
\hline 7 & お知らせ下さる & 16 & ご連絡下さる \\
\hline 8 & お知らせ下こいます & 17 & ご連絡下さいます \\
\hline 9 & お知らせになられる & 18 & ご連絡になられる \\
\hline
\end{tabular}

付表 4.2 発話意図: invite, 尊敬語

\begin{tabular}{|c|c|c|c|}
\hline No. & 和語系表現 & No. & 漢語系表現 \\
\hline 1 & 招< & 10 & 招待する \\
\hline 2 & 招きます & 11 & 招待します \\
\hline 3 & 押招きなさる & 12 & ご招待なさる \\
\hline 4 & 扔招きなといます & 13 & ご招待なさいます \\
\hline 5 & 押招きになる & 14 & ご招待になる \\
\hline 6 & 抢招きになります & 15 & ご招待になります \\
\hline 7 & 捄招き下さるる & 16 & ご招待下さるる \\
\hline 8 & お招き下といます & 17 & 招待下さいます \\
\hline 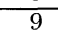 & 扩招き & 18 & になられる \\
\hline
\end{tabular}




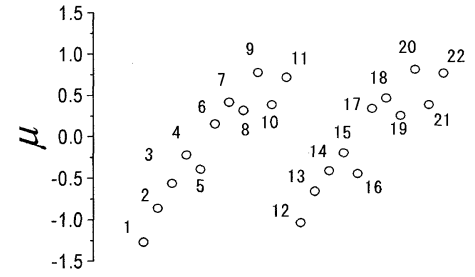

付図 $1.1 \mu$ (発話意図：use, 謙譲語)

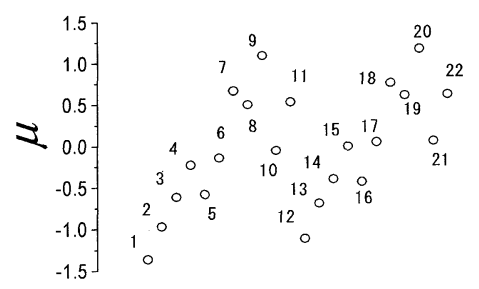

付図 $2.1 \mu$ (発話意図: explain, 謙譲語)

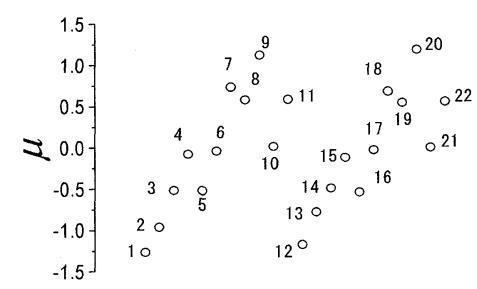

付図 $3.1 \mu$ (発話意図：inform, 謙譲語)

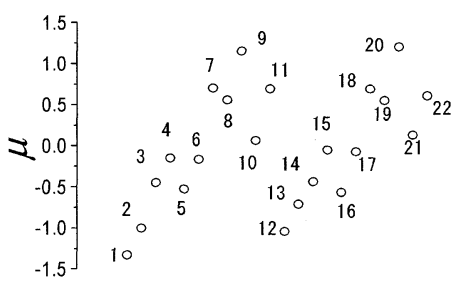

付図 $4.1 \mu$ (発話意図 : invite, 謙譲語)

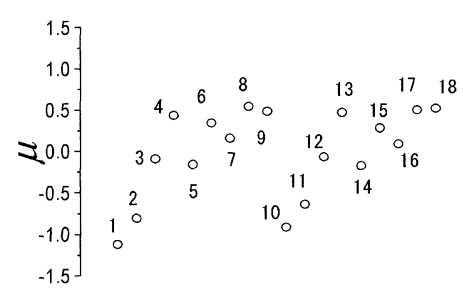

付図 $1.2 \mu$ (発話意図: use, 尊敬語)

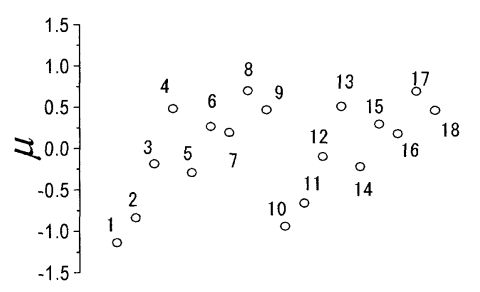

付図 $2.2 \mu$ (発話意図：explain, 尊敬語)

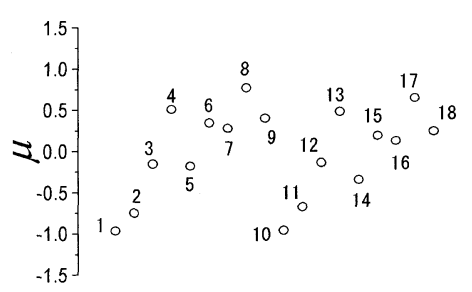

付図 $3.2 \mu$ (発話意図: inform, 尊敬語)

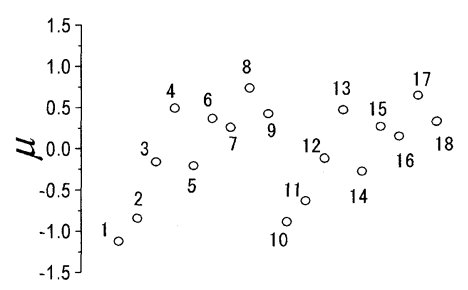

付図 $4.2 \mu$ (発話意図：invite, 尊敬語) 


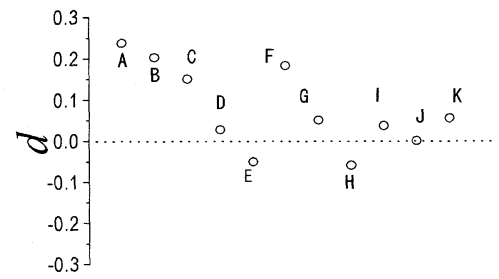

付図 $5.1 d$ (発話意図：use, 謙譲語)

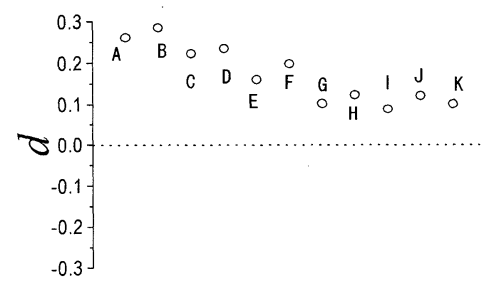

付図 $6.1 d$ (発話意図：explain, 謙譲語)

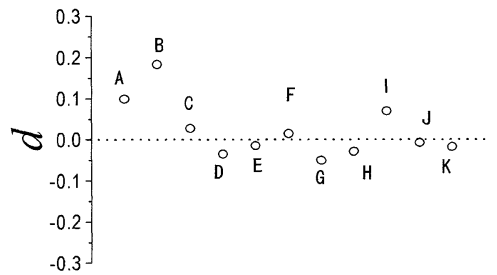

付図 $7.1 d$ (発話意図 : inform, 謙譲語)

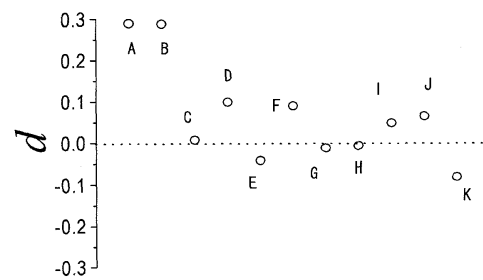

付図 $8.1 d$ (発話意図：invite, 謙譲語)

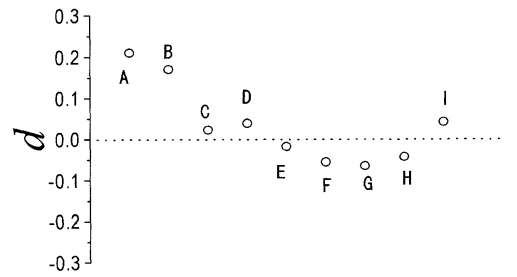

付図 $5.2 d$ (発話意図: use, 尊敬語)

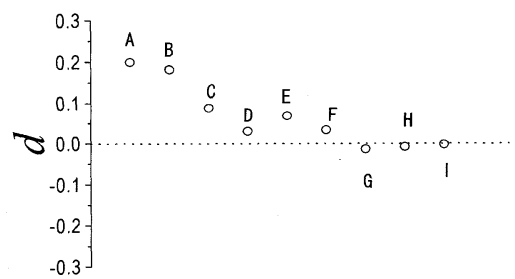

付図 $6.2 d$ (発話意図：explain, 尊敬語)

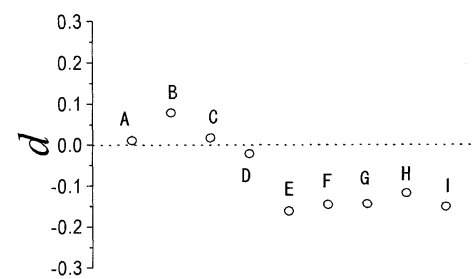

付図 $7.2 d$ (発話意図：inform, 尊敬語)

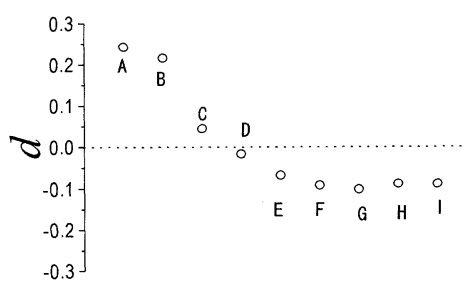

付図 $8.2 d$ (発話意図: invite, 尊敬語) 


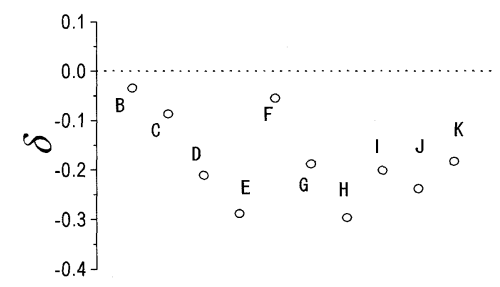

付図 $9.1 \delta$ (発話意図：use, 謙譲語)

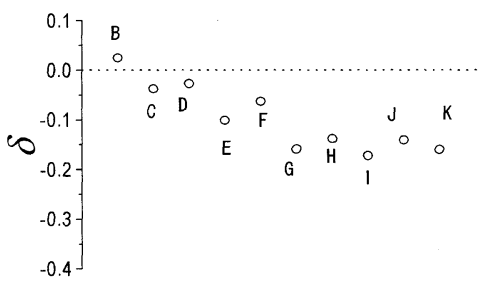

付図 $10.1 \delta$ (発話意図：explain, 謙譲語)

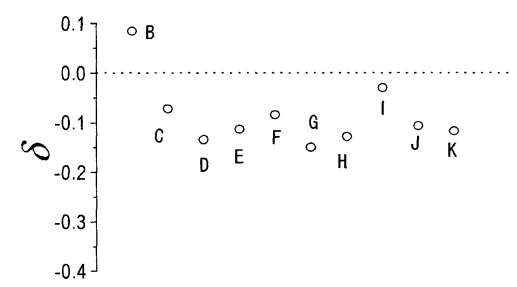

付図 $11.1 \delta$ (発話意図：inform, 謙譲語)

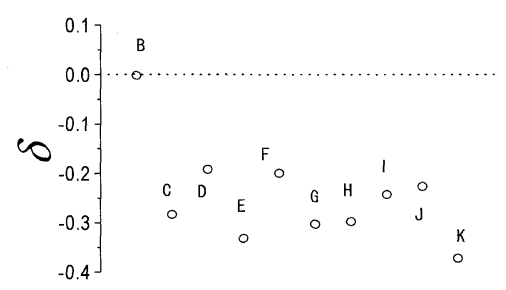

付図 $12.1 \delta$ (発話意図: invite, 謙譲語)

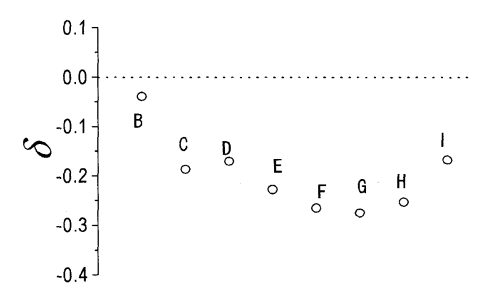

付図 $9.2 \delta$ (発話意図：use, 尊敬語)

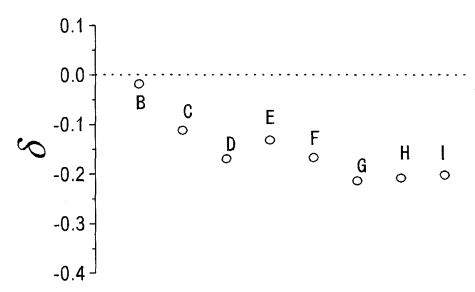

付図 $10.2 \delta$ (発話意図：explain, 尊敬語)

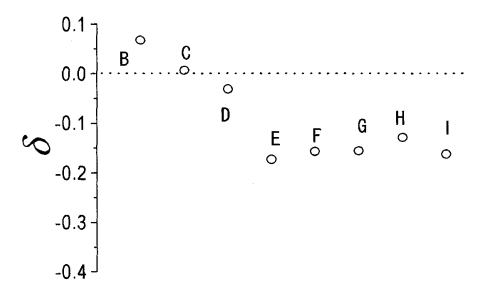

付図 $11.2 \delta$ (発話意図 : inform, 尊敬語)

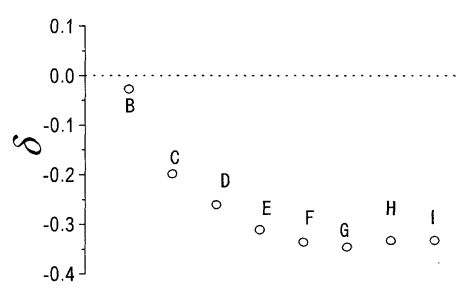

付図 $12.2 \delta$ (発話意図：invite, 尊敬語) 


\section{略歴}

丸元 聡子: 1996 年東京女子大学文理学部日本文学科卒業. 同年, 財団法人計 量計画研究所入所, 2000 年-2001 年, 通信 ·放送機構／通信総合研究所（現： 情報通信研究機構）に出向. 現在, 財団法人計量計画研究所言語情報研究室 研究員. 自然言語処理の研究に従事. 言語処理学会, 計量国語学会, 電子情 報通信学会, 各会員.

白土 保: 電気通信大計算機科学科卒. 1986 年電波研究所（現N I C T) 入所. 鹿島センター, 平磯センター, 関西先端研究センター, けいはんなセンター, 総務省情報通信政策局勤務を経てけいはんなセンター勤務. 主任研究員. 専 門分野は, 言語心理, 音楽音響, 感性情報処理. 日本音響学会, 電子情報通 信学会, 各会員. 工学博士.

井佐原 均: 1980 年京都大学大学院修士課程修了. 博士 (工学). 同年, 通商 産業省電子技術総合研究所入所. 1995 年郵政省通信総合研究所. 現在, 独立 行政法人情報通信研究機構けいはんな情報通信融合研究センター自然言語グ ループリーダーおよびタイ自然言語ラボラトリー長. 自然言語処理, 語彙意 味論の研究に従事. 言語処理学会, 情報処理学会, 人工知能学会, 日本認知 科学会, ACL, 各会員. 